\title{
Using topographic map interpretation methods to determine Tookany (Tacony) Creek erosion history upstream from Philadelphia, Pennsylvania, USA
}

\author{
Eric Clausen ${ }^{1}$ \\ ${ }^{1}$ Jenkintown, PA. USA \\ Correspondence: Eric N. Clausen, 100 West Ave D-17, Jenkintown, PA, 19046, USA. E-mail: \\ eric2clausen@gmail.com
}

Received: October 26, 2016

Accepted: November 18, 2016

Online Published: December 2, 2016

doi:10.5539/jgg.v8n4p30

URL: http://dx.doi.org/10.5539/jgg.v8n4p30

\begin{abstract}
Topographic map interpretation methods are used to determine erosional landform origins in and adjacent to the Tookany (Tacony) Creek drainage basin, located upstream from and adjacent to Philadelphia, PA. Five wind gaps notched into the Tookany-Wissahickon Creek drainage divide (which is also the Delaware-Schuylkill River drainage divide), a deep through valley crossing the Tookany-Pennypack Creek drainage divide, a Tookany Creek elbow of capture, orientations of Tookany Creek tributary valleys, a narrow valley carved in erosion resistant metamorphic bedrock, and the relationship of a major Tookany Creek direction change with a Pennypack Creek elbow of capture and a Pennypack Creek barbed tributary are used along with other evidence to reconstruct how a deep south oriented Tookany Creek valley eroded headward across massive southwest oriented flood flow. The flood flow origin cannot be determined from Tookany Creek drainage basin evidence, but may have been derived from a melting continental ice sheet, and originally flowed across the Tookany Creek drainage basin region on a low gradient topographic surface equivalent in elevation to or higher than the highest present day Tookany Creek drainage divide elevations with the water flowing in a complex of shallow diverging and converging channels that had formed by scouring of less resistant bedrock units and zones. William Morris Davis, sometimes referred to as the father of North American geomorphology, spent much of his boyhood and several years as a young man living in the Tookany Creek drainage basin and all landforms discussed here were within walking distance of his home and can be identified on a topographic map published while he was developing and promoting his erosion cycle ideas. Davis never published about Tookany Creek drainage basin erosion history, but he developed and promoted uniformitarian and erosion cycle models that failed to recognize the significance of Tookany Creek drainage basin erosional landform features providing evidence of the immense floods that once crossed present day drainage divides and eroded the Tookany Creek drainage basin.
\end{abstract}

Keywords: drainage divide, Pennypack Creek, Tookany Creek, William Morris Davis, wind gap, Wissahickon Creek

\section{Introduction}

\subsection{What is the William Morris Davis Relationship with the Tookany Creek Drainage Basin?}

William Morris Davis (1850-1934) played a major role in shaping the science of geomorphology, and is sometimes referred to as the "father of North American geomorphology." Davis is best known for descriptive landform interpretations and his cycle of erosion or geographical erosion cycle. Davis first developed his erosion cycle ideas in the 1880s and subsequently he, his students, and their students enhanced and promoted the concept so the Davis erosion cycle interpretation became the dominant geomorphology paradigm used throughout much the early $20^{\text {th }}$ century (Orme, 2007). Important to the Davis erosion cycle idea was the uniformitarianism paradigm applied by Davis when describing landform evolution. While most researchers today consider the Davis erosion cycle interpretations obsolete the underlying Davis uniformitarianism paradigm still influences many landform evolution studies.

Tookany Creek drains most of Cheltenham Township, located in the Upper Piedmont Section of the Piedmont Province in Montgomery County, PA (USA) and adjacent to the City of Philadelphia (shown as Philadelphia County in figure 1). In Cheltenham Township the stream drains an area slightly larger than 20 square kilometers. 
After leaving Cheltenham Township Tookany Creek enters Philadelphia where its name changes to Tacony Creek and it flows in a southwest and then south direction separating northeast city neighborhoods from the main city to the west before reaching the southwest oriented Delaware River as Frankford Creek. West and north of the Tookany Creek drainage basin is the Wissahickon Creek drainage basin. East of the Tookany Creek drainage basin is the Pennypack Creek drainage basin.

Davis spent much of his boyhood and several years as a young adult living in the Tookany Creek drainage basin (Clausen, 2015). His home was located near the Tookany-Wissahickon Creek (also Delaware-Schulykill River) drainage divide. By walking 1 or 2 kilometers to the east young Davis could watch Tookany Creek water flow to the Delaware River or by walking 2 to 4 kilometers to the west he could watch Wissahickon Creek water flow to the Schuylkill River. Near his family's home were headwaters of a northeast oriented barbed tributary (Mill Run) flowing to a southeast oriented Tookany Creek valley segment, which a short distance downstream turned to become a southwest oriented Tookany Creek valley segment. Upstream were five wind gaps notched into the Tookany-Wissahickon Creek drainage divide and a well defined through valley across the Tookany-Pennypack Creek drainage divide. Both Tookany Creek and Wissahickon Creek have deep valleys with steep walls carved in erosion resistant metamorphic bedrock. A rolling upland on which the Davis home was located separates the two valleys.

While living in the Tookany Creek drainage basin Davis had no reason to believe the study of landforms would become important in his future career. His father was President of the Barclay Coal Company (Chorley, R. J., Beckinsale, R. P, \& Dunn, A. J., 1973) and there may have been expectations young Davis would take an interest in coal mining. These expectations may be why young Davis studied mining engineering while a student at Harvard. But Davis also had interests in astronomy, meteorology, and entomology and immediately after graduation took a job as a meteorologist at an Argentine observatory where he spent his free time observing local insects. After three years in Argentina he returned to the family home and worked in the Barclay Coal Company office until being invited to teach as an instructor at Harvard University. It was only while trying to secure his shaky Harvard position that his landform origin hypotheses developed (Chorley et al, 1973).

Davis claimed ideas for his geographic erosion cycle hypotheses originated while working in the Montana Crazy Mountains (Chorley et al, 1973), but observations made in the Tookany Creek drainage basin as a boy and young man must have played an important role. Topographic maps of the Tookany Creek drainage basin were first published after Davis secured his Harvard University faculty position. The United States Geological Survey (USGS) 1:62:500 scale Germantown PA map (from which figure 1 is taken) was published in 1896 when Davis was actively developing and promoting his geographical erosion cycle and uniformitarianism hypotheses (e.g. Davis, 1899). Davis apparently had access to topographic maps almost as soon as they were issued as shown by dates of his publications (e.g. Davis, 1889a), but no evidence was found that any of his numerous publications specifically discussed Germantown map evidence.

Whatever Davis as a boy and young man observed in the Tookany Creek drainage basin apparently did not conflict with his (1895) uniformitarianism paradigm:

"The deepening of a valley by its stream is a slow process; the widening of the valley by the wasting of its slopes is still slower; the development of subsequent streams by headward erosion, the accompanying migration of divides, and the resulting rearrangement and adjustment of waterways are slowest of all. The deepening of a canyon is a rapid process compared to the creeping of a divide. ...Here, if anywhere, the slow processes of uniformitarianism are justified, and the hurried processes of catastrophism are completely at fault. To attempt to substantiate principles so widely accepted as those of uniformitarianism may seem to some an unnecessary task. It might be compared to adducing new evidence in support of the law of gravitation."

This uniformitarianism concept was not unique to Davis and at that time also reflected the view of many geologists. For example, Bascom, F., Clark, W. B., Darton, N. H., Knapp, G. N., Kuemmel, H. B., Miller, B. L., and Salisbury, R. D. (1909) who mapped geology in the Germantown and adjacent quadrangles describe a regional geologic history consistent with the Davis uniformitarianism paradigm. 


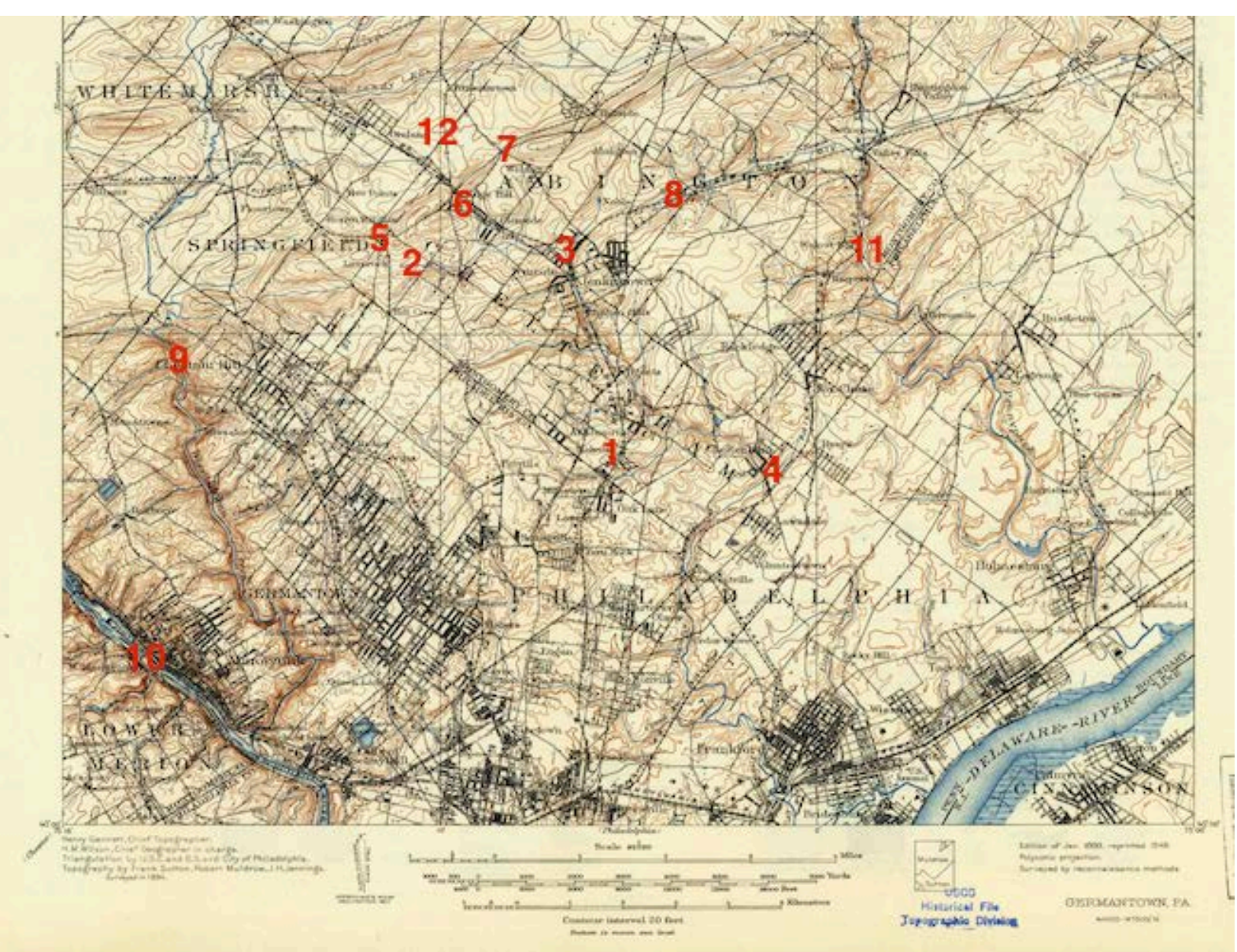

Figure 1. Section of the USGS 1896 Germantown 1:62,500 topographic map (20-foot contour interval) showing the Tookany Creek and adjacent drainage basins. Number 1 identifies the Davis family home, 2-Tookany Creek headwaters, 3-Jenkintown elbow of capture, 4-Cheltenham abrupt direction change, 5-Seminary wind gap, 6Edge Hill wind gap, 7-Weldon wind gap, 8-Jenkintown-Bethayres through valley, 9-Wissahickon Creek gorge, 10-Schuylkill River, 11- Pennypack Creek, and 12-Chester Valley. Tookany and Pennypack Creeks flow to the southwest oriented Delaware River

\subsection{Why is the Davis Uniformitarianism Paradigm Important Today?}

The Davis uniformitarianism paradigm implies landscapes evolve slowly over extremely long periods of time measured in millions if not tens of millions of years. While Thornbury (1969, p 29) argues, "Little of the earth's topography is older than Tertiary and most of it is no older than the Pleistocene” Bishop (2007) claims the Thornbury conclusion is based on "measured erosion rates that were almost certainly too high because of anthropogenic disturbance" and even "when more 'reasonable' long-term erosion rates were used... the Davisian erosion cycle required between 10 and 25 Myr to run its full course.” Newer research approaches to studying landform evolution that replaced the Davis developed erosion cycle models do not challenge the Davis concept that landscapes evolve slowly over long periods of time. For example Hack's (1957) dynamic equilibrium scheme for landscape evolution, while quite different from the Davis erosion cycle concept also implies slow processes of landscape evolution. Likewise quantitative geomorphology introduced by Horton (1945) and Strahler (1952) does not challenge the Davis uniformitarianism model.

Bishop in his 2007 review paper summarizes more recent work related to long-term landscape evolution, which the plate tectonics revolution and the "development of numerical models that explore the links between tectonic processes and surface processes" stimulated. Bishop points out how breakthroughs in analytical and geochronological techniques are enabling researchers to confirm, "more sophisticated Davisian-type numerical models of slope lowering under conditions of tectonic stability (no active rock uplift), and... will indicate that the Davis and Hack models are not mutually exclusive.” In other words the Bishop (2007) paper suggests researchers using the newly developed analytical and geochronological techniques are in many cases indirectly 
making use of the Davis uniformitarianism paradigm and rejecting the Thornbury (1969) proposed Pleistocene erosion paradigm. But, what if Davis overlooked significant evidence when developing his erosion cycle models and as a result his uniformitarianism paradigm is flawed? Is it possible Davis pointed geomorphologists in an unproductive direction and the geomorphology research community needs to study, perhaps for the first time, landform features Davis overlooked?

\subsection{How was the Tookany Creek Drainage Basin Eroded?}

The Davis uniformitarianism paradigm, while permitting wind gaps, through valleys, barbed tributaries, and elbows of capture, implies such features are rarely formed. Yet in and surrounding the Tookany Creek drainage basin such landform features are common. The Hack dynamic equilibrium paradigm also fails to provide a good explanation for abundant wind gaps, through valleys, barbed tributaries, and elbows of capture. But could a paradigm defined by headward erosion of deep valleys into an upland surface on which massive floods are flowing in a complex of diverging and converging channels explain the formation of wind gaps, through valleys, barbed tributaries, and elbows of capture? J H. Bretz in the 1920s proposed in a series of papers that an immense flood eroded the channeled scabland in eastern Washington State (e.g. Bretz, 1923). The geology research community of that time, which W. M. Davis had strongly influenced, overwhelmingly rejected the Brez's hypothesis (Baker in 1981 prepared a book containing some of the original papers published during the ensuing channeled scabland debate). Immense floods flowing in giant anastomosing complexes of diverging and converging channels are now commonly used to explain eastern Washington State landscape features, but are rarely used to explain landform evolution in other regions, especially in southeast Pennsylvania where the Tookany Creek drainage basin is located.

The study described here interpreted topographic map evidence to determine how the wind gaps, through valleys, barbed tributaries, elbows of capture, valley orientations, and similar landform features found within and near the relatively small Tookany Creek drainage basin (and near the former Davis boyhood home) were formed. The goal was to use these erosional landforms like pieces of a picture puzzle to reconstruct a coherent sequence of erosion events that would explain all of the observed landform evidence. Since Davis should have been intimately familiar with Tookany Creek drainage basin landforms the reconstructed Tookany Creek drainage basin erosion history should also answer the question of whether or not Davis overlooked significant landform features when developing and promoting his erosion cycle and uniformitarianism paradigms and if so whether or not his still surviving uniformitarian paradigm is now causing modern day geomorphologists to overlook the importance of similar landform features.

\section{Method}

Topographic maps used in this study were obtained from the United States Geological Survey Historical Map Collection website and Pennsylvania Department of Conservation and Natural Resources (DCNR) Interactive Map Resources website. The DCNR Interactive Map Resources website also provided access to a digital Pennsylvania geologic map used to identify bedrock units underlying the Tookany Creek drainage basin. Topographic maps available on the DCNR Interactive Map Resources website were particularly useful as they could be scrolled in any direction, however the USGS website identified the Frankford and Germantown (and to a lesser degree the Ambler and Hatboro) 1:24,000 scale topographic maps as being the specific maps from which the DCNR website map data had been obtained. Elevations on all maps used in this study were shown in feet and for that reason all elevations given in this paper are also in feet.

This study began by identifying landforms of interest along the Tookany-Wissahickon Creek (also the Delaware-Schuylkill River) divide and on the Tookany-Pennypack Creek divide. The Tookany-Wissahickon Creek divide is at the southern end of the Delaware-Schuylkill River divide and potentially provides information as to how those two much larger drainage basins evolved. Specifically identified were five identifiable wind gaps notched into the Tookany-Wissahickon divide and a deep through valley crossing the Tookany-Pennypack Creek divide. Two Tookany Creek abrupt direction changes, a narrow valley downstream from Jenkintown, and a less obvious through valley across the Pennypack-Tookany Creek divide and barbed tributaries were also observed. The through valleys and wind gaps were interpreted to be evidence water once crossed present day drainage basin divides at multiple locations.

The identified wind gaps and through valleys were interpreted to be evidence a completely different drainage system had crossed the region prior to Tookany Creek drainage basin erosion. The nature of this earlier drainage system was determined by looking at the locations and number of wind gaps and through valleys and also at the orientations of Tookany Creek (and some Wissahickon and Pennypack Creek) valley segments and tributaries, which were interpreted to reflect previous drainage system channel orientations and locations. The wind gaps, 
through valleys, and valley orientations suggested a large number of drainage channels had once crossed the Tookany Creek drainage basin region and that at least some of the earlier drainage channels had converged and diverged within or near the present day Tookany Creek drainage basin. These interpretations strongly suggested that prior to Tookany Creek drainage basin erosion a large complex of diverging and converging channels had crossed the entire region.

Next the barbed tributaries and elbows of capture were considered to be evidence a deeper Tookany Creek valley had eroded headward across this anastomosing complex of channels and the barbed tributaries had formed when water on downstream ends of beheaded channels had reversed to move toward the newly eroded and deeper Tookany Creek valley. Reversal of flow in beheaded channels was interpreted to only have been possible if the beheaded channel had been a low gradient channel suggesting the anastomosing channel complex had formed on a low gradient topographic surface. Erosion of the barbed tributary valleys was interpreted to have been by water captured from diverging and converging channels that Tookany Creek valley headward erosion had not yet beheaded. Valley depths and the erosion resistant nature of bedrock into which the Tookany Creek valley has been eroded were considered to be evidence that headward erosion of a deep Tookany Creek valley into the region required immense water volumes. These considerations suggested Tookany Creek valley headward erosion had been across an anastomosing channel complex through which massive volumes of water were flowing on a low gradient topographic surface at least as high or higher than the highest Tookany Creek drainage basin elevations today.

\section{Results}

Topographic map interpretation results for the identified Tookany Creek drainage basin wind gaps, through valleys, barbed tributaries, and elbows of capture or major valley direction changes are described below. While recent 1:24,000 scale topographic maps with 10- or 20-foot contour intervals were used all landform features described here are located within 6 kilometers of the former Davis home and are also recognizable on the 1896 Germantown topographic map with its 20 -foot contour interval.

\subsection{Laverock and Seminary Wind Gaps}

Figure 2 with a 10-foot contour interval shows two closely spaced wind gaps both notched into the Tookany-Wissahickon (Delaware-Schuylkill) drainage divide. The red four-lane highway passes through the Seminary wind gap (next to Westminster Theological Seminary) while the Laverock wind gap is located north of the word "Laverock". Both wind gaps appear to have had natural floor elevations of between 350 and 360 feet. The Seminary wind gap is notched into a northeast oriented ridge known as Edge Hill. The grade of an abandoned railroad can be seen extending in a north direction through the gap. That railroad is shown on the 1896 Germantown map, but was used primarily for freight traffic so Davis probably never rode on it.

The Edge Hill ridge according to the Pennsylvania DCNR Interactive Map Resources digital geologic map is composed of Cambrian Chickies Formation with quartzite the dominant rock type and marks the boundary between the Piedmont Upland Section (south) and Piedmont Lowland Section (Potter, 1999). Felsic gneiss of Precambrian age underlies the region south of the Edge Hill ridge while north of the ridge is the carbonate floored Chester Valley with Cambrian or Ordovician Conestoga Formation limestone being adjacent to the Edge Hill ridge. Cambrian Elbrook Formation (calcareous shale) and Cambrian Ledger Formation (dolomite) underlie unseen Chester Valley areas north of figure 2. Camp Hill, which is a linear ridge like Edge Hill, forms the unseen Chester Valley north boundary and north of the Camp Hill ridge Triassic age sedimentary rocks underlie the Piedmont Province Gettysburg-Newark Lowland Section. 


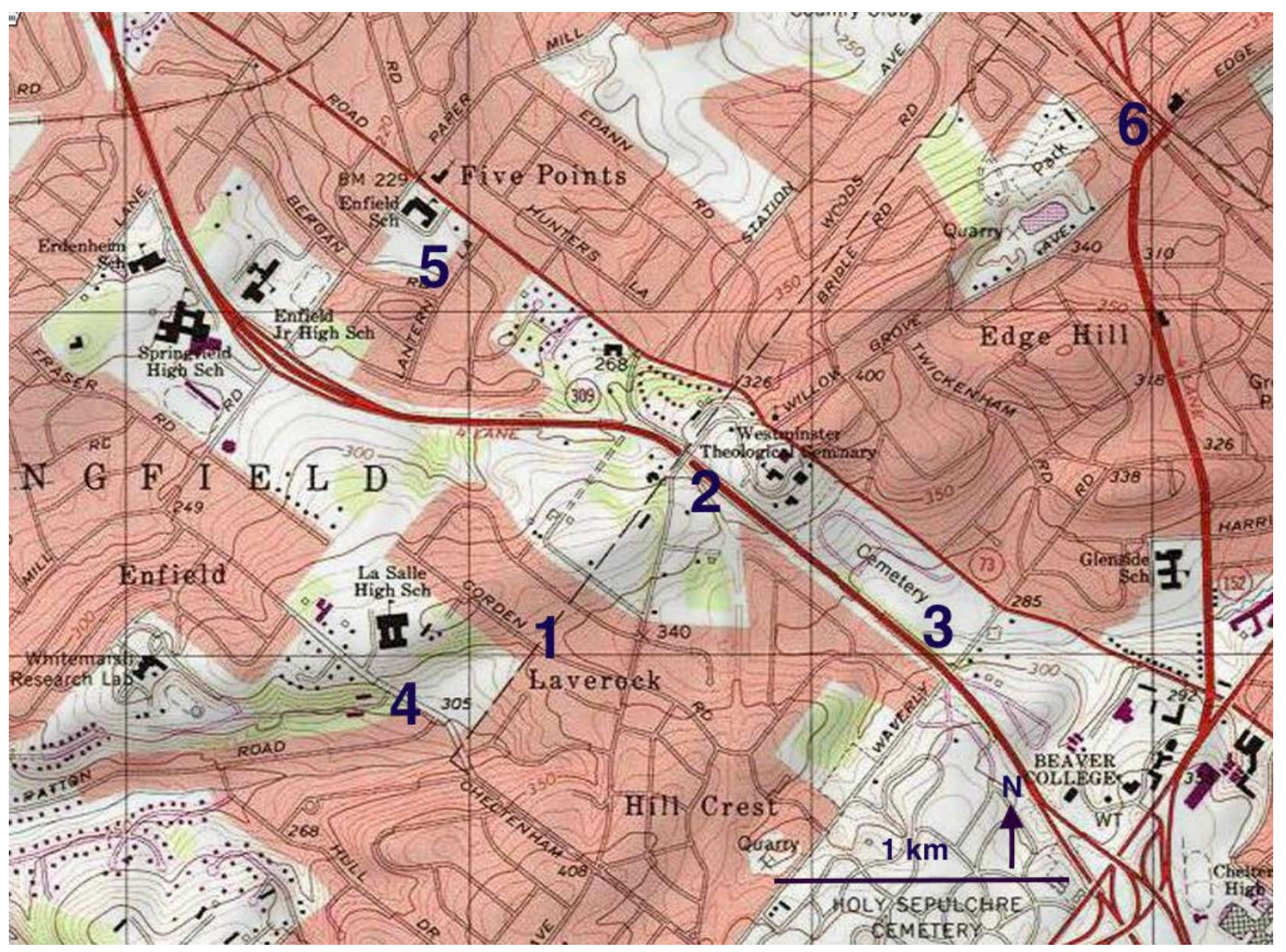

Figure 2. USGS 1:24,000 topographic map (with a 10-foot contour interval) taken from Pennsylvania DCNR Interactive Map Resources website showing Laverock wind gap (1), Seminary wind gap (2), east oriented Tookany Creek headwaters (3), west oriented Wissahickon Creek tributary headwaters (4), a northwest oriented tributary (5) to an unseen west oriented Wissahickon Creek tributary in the Chester Valley, and the Edge Hill wind gap (6). La Salle High School is located on the Edge Hill ridge

East oriented Tookany Creek headwaters are located east of the Laverock wind gap just north of Beaver College (now Arcadia University). West oriented headwaters of a Wissahickon Creek tributary are located west of the Laverock wind gap. The wind gap is evidence water once flowed one way or the other through the gap and dismemberment of that flow required one of the two streams now flowing in opposite directions to have reversed its flow direction. A flow direction reversal could only have occurred if headward erosion of a much deeper valley beheaded a low gradient channel. However, the two streams now flowing in opposite directions from the Laverock wind gap today have steep gradients as they both flow into deep valleys. Somehow after the earlier channel had been dismembered water continued to flow into the reversed channel so as to erode the deep valley seen today.

A saddle notched into the Edge Hill ridge north of the "L" in the word "Laverock" may have been used by south oriented water flowing to the Laverock wind gap location that helped to erode the deep reversed flow valley. The possibility of north and east oriented flow is rejected because the Tookany and Wissahickon drainage basins are today both south oriented drainage basins. If south oriented water did flow to the Laverock wind gap location then at that time Chester Valley elevations (north of Edge Hill) must have been greater than 380 feet, or significantly higher than they are now. Figure 3 illustrates how the Laverock and Seminary wind gaps are located midway between south oriented Wissahickon Creek (west) and the south oriented Tookany Creek valley downstream from the Jenkintown rail junction elbow of capture. Prior to being beheaded and reversed by Tookany Creek valley headward erosion water flowed in a west direction from the Jenkintown rail junction elbow of capture across the Laverock wind gap to join Wissahickon Creek just north of the present day Wissahickon gorge (seen in the southwest corner of figure 3). Note how the west oriented Wissahickon Creek tributary originating near the Laverock wind gap turns to flow through a water gap south of Erdenheim and joins 
a southwest oriented Wissahickon Creek tributary, which is much easier to explain if the water in that tributary valley always flowed in a west direction.

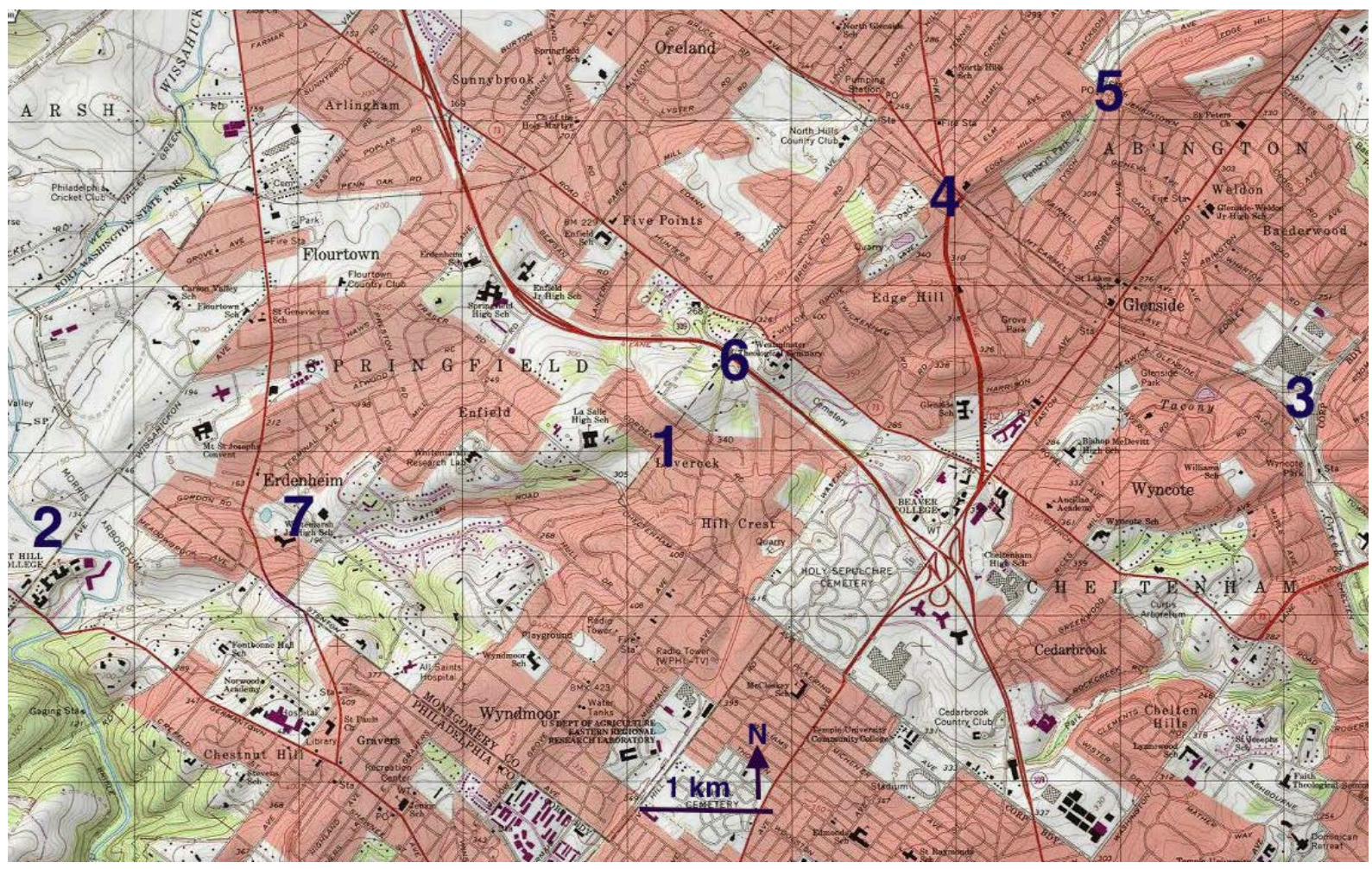

Figure 3. USGS 1:24,000 topographic maps (with a 10-foot contour interval) showing relationship of Laverock wind gap (1) to Wissahickon Creek (2), Jenkintown elbow capture (3), Edge Hill wind gap (4), Weldon wind gap (5), and Seminary wind gap (6). The west oriented Wissahickon tributary originating west of the Laverock wind gap crosses the Edge Hill ridge in a water gap (7) to enter the Chester Valley before joining a southwest oriented stream that flows to Wissahickon Creek near point 2

The Seminary wind gap is located further east on the Edge Hill ridge and its natural floor elevation was probably 30-40 feet lower than the floor elevation of the saddle directly north of the Laverock wind gap (which suggests south oriented water moved through it after flow across the higher elevation saddle ceased). The gap links the east oriented Tookany Creek valley with the valley of a northwest and west oriented Wissahickon Creek tributary (on the Chester Valley floor). The Seminary wind gap location is such that water flowing through it would have moved to the east oriented Tookany Creek headwaters valley confirming the hypothesis that the Tookany Creek headwaters flow direction was reversed during the dismemberment of a west oriented flow channel leading to the deep south oriented Wissahickon Creek gorge (seen in figure 3 southwest corner). However, prior to the beheading and reversal of flow that created the east oriented Tookany Creek headwaters it is possible a west oriented diverging channel led in a northwest direction through the Seminary wind gap to converge with a west oriented channel located in what was at that time the yet to be eroded Chester Valley north of the Edge Hill Ridge.

Evidence seen in figures 2 and 3 documents dismemberment of a west oriented flow channel (south of the Edge Hill ridge) that was moving water to the south oriented Wissahickon gorge. Since the original flow direction was to the west the evidence also suggests the west oriented flow was eroding the deep west oriented Wissahickon Creek tributary valley headward toward the Laverock wind gap location, which means the south oriented Wissahickon gorge existed prior to flow dismemberment. Further the figure 2 and 3 evidence documents that following the flow dismemberment elevations in the Chester Valley (north of the Edge Hill ridge) were high enough that enough water could spill from the Chester Valley in a south direction into the reversed flow channel to erode a deep east oriented valley while at the same time there was enough west and southwest oriented water moving north of the Edge Hill ridge toward the south oriented Wissahickon Creek valley to significantly lower 
the Chester Valley floor.

\subsection{Edge Hill, Weldon, and Highland Wind Gaps}

Figure 4 illustrates in detail the Edge Hill wind gap located where the railroad near the figure southwest corner goes under a red 4-lane highway (also seen figures 2 and 3), the Weldon wind gap located at the unnamed railroad station north of the "A" in the word "ABINGTON", and the Highland wind gap located near the Highland School (in northeast corner of figure 4). The Weldon gap was known as Tyson's Gap when Davis lived in the region (Camburn, 1977). Railroad and highway construction has not significantly altered the Weldon gap elevation, where a spot elevation of 326 feet is shown, or the Highland wind gap floor (elevation between 380 and 390 feet), but has deepened the Edge Hill wind gap. Today the highway bridge over the railroad is built at approximately the original wind gap floor elevation of between 320 and 330 feet while the railroad passes underneath in a deeper railroad excavated cut. The railroad through the Edge Hill gap was constructed in 1854 and had a station near the former W.M. Davis home.

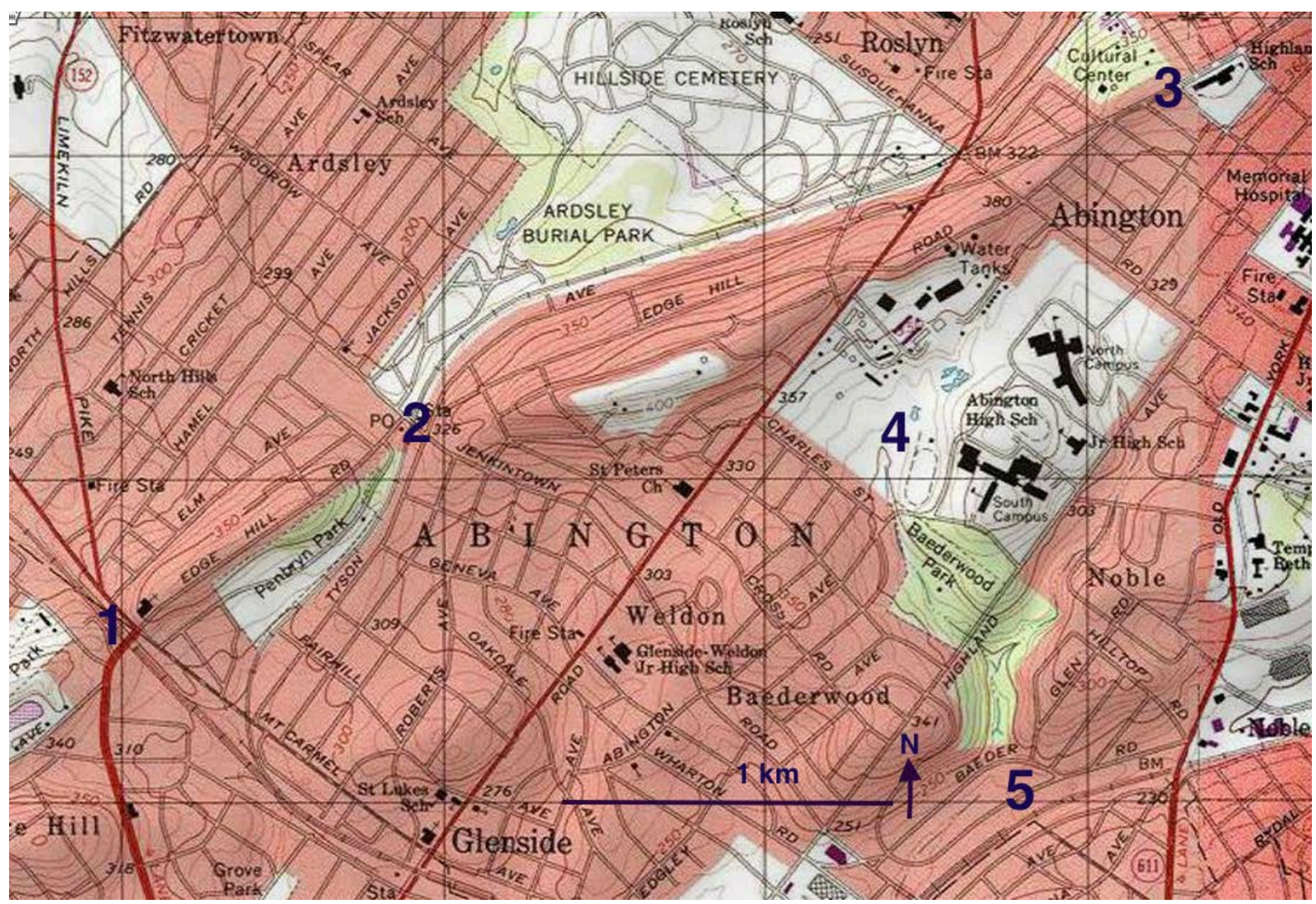

Figure 4. USGS 1:24,000 topographic map taken from the Pennsylvania DCNR Interactive Map Resources website (with a 10 -foot contour interval except along the lower $90 \%$ of the eastern edge where the contour interval is 20 feet) showing the Edge Hill wind gap (1), Weldon wind gap (2), Highland wind gap (3), headwaters of south and southwest oriented Baederwood Creek (4), and western end of the Jenkintown-Bethayres through valley (5).

The Edge Hill ridge elevation exceeds 410 feet southwest of the Edge Hill wind gap (near the Westminster Seminary) and exceeds 420 feet between the Weldon and Highland gaps, but at multiple locations is slightly lower. Lower ridge elevations at various locations suggest considerable water flowed across the ridge and that the water was not confined to the wind gap channels. North of the Edge Hill wind gap are headwaters of a west oriented Wissahickon Creek tributary (seen in figure 3) and the Edge Hill wind gap orientation suggests prior to Tookany Creek valley headward erosion a diverging channel (diverging from a west oriented channel south of the present Edge Hill ridge) had flowed in a northwest direction to converge with a west oriented channel in what at that time was the yet to be eroded Chester Valley. If so, headward erosion of the much deeper Tookany Creek valley beheaded and reversed flow through the Edge Hill wind gap until Chester Valley lowering 
beheaded the then south oriented flow that had been moving into the newly eroded Tookany Creek valley. The Weldon and Highland wind gap orientations suggest southwest oriented flow moved to west oriented channels south of the present day Edge Hill ridge before Tookany Creek valley headward erosion captured that flow. Today streams flowing along segments of these routes are incorporated into the Glenside sewer system, but are shown on the 1896 Germantown map (figure 1).

\subsection{Summary of the Wind Gap Evidence}

Map evidence (only partially seen here) documents three west oriented streams draining the Chester Valley (north of the Edge Hill ridge) to south oriented Wissahickon Creek. This evidence strongly suggests that while water was spilling across the Edge Hill ridge and eroding the Seminary, Edge Hill, Weldon, and Highland wind gaps (and perhaps lowering the Edge Hill ridge at other locations) water was also eroding three west oriented valleys headward into the carbonate bedrock underlying the Chester Valley floor. Further, previously discussed evidence from the Laverock wind gap demonstrates that prior to the flow reversal that created the east oriented Tookany Creek headwaters water also flowed in a west direction south of the Edge Hill ridge. The Seminary and Edge Hill wind gap orientations suggest that for a time channels may have diverged from the west oriented channel south of the present day ridge and then converged with west oriented channels in the yet to be eroded Chester Valley. Weldon and Highland wind gap orientations suggest water diverged from west oriented channels in what was then the yet to be eroded Chester Valley and converged with west oriented channels south of the Edge Hill ridge. These diverging and converging channels appear to have been components of a west or southwest oriented anastomosing channel complex through which massive volumes of water flowed across the entire region.

This west or southwest oriented complex of diverging and converging channels must have initially developed on a low gradient regional topographic surface equivalent in elevation (or higher than) the highest Edge Hill elevations seen today. Headward erosion of the deep south-oriented Wissahickon Creek valley into this former topographic surface captured the southwest and west oriented flow and also significantly lowered base level permitting the massive southwest oriented flow to erode the Chester Valley carbonate rock floor headward in an east-northeast direction. At the same time headward erosion of the deep south-oriented Tookany Creek valley beheaded and reversed a west oriented flow channel moving water to the newly eroded Wissahickon Creek valley south of the present day Edge Hill ridge, captured southwest oriented flow channels that crossed what is now the Edge Hill ridge and also beheaded and reversed diverging northwest oriented flow channels.

The west oriented Laverock gap channel valley eroded headward from the actively eroding south oriented Wissahickon valley head while the Wissahickon valley was still eroding headward across the Chester Valley with the result that elevations south of the Edge Hill ridge were lowered as Chester Valley lowering was just beginning. Chester Valley lowering proceeded from west to east and water ceased to flow through the Seminary and Edge Hill wind gaps while water still flowed through the Weldon and Highland gaps. The Highland gap, being near the Chester Valley east end, in spite of its higher floor elevation was probably the last of the south oriented channels moving water across the Edge Hill ridge to be beheaded by headward erosion of west oriented (Chester Valley) Wissahickon Creek tributary valleys. Headward erosion of the deep south-oriented Pennypack Creek valley seen in figures 1 and 5 ended all west and southwest oriented flow to both the newly eroded Tookany Creek drainage basin and the Chester Valley.

\subsection{Jenkintown Rail Junction Elbow of Capture and the Jenkintown-Bethayres through Valley}

East of the Tookany Creek elbow capture near the Jenkintown rail junction and the east oriented Tookany Creek headwaters (and upstream from the south oriented Tookany Creek valley) is an east-northeast oriented through valley seen in figure 5 that extends from the elbow of capture to south oriented Pennypack Creek. The through valley is drained by east-northeast oriented Meadow Brook to Pennypack Creek and a southwest oriented Baederwood Creek segment (the stream flows south before entering the through valley where it turns to flow to Tookany Creek at the elbow of capture). Tookany Creek crosses the 200-foot contour line downstream from its elbow of capture while a benchmark near where Meadow Brook joins Pennypack Creek has an elevation of 145 feet. The Tookany-Pennypack Creek drainage divide on the through valley floor is located near the number 1 and has an elevation of between 220 and 230 feet. 


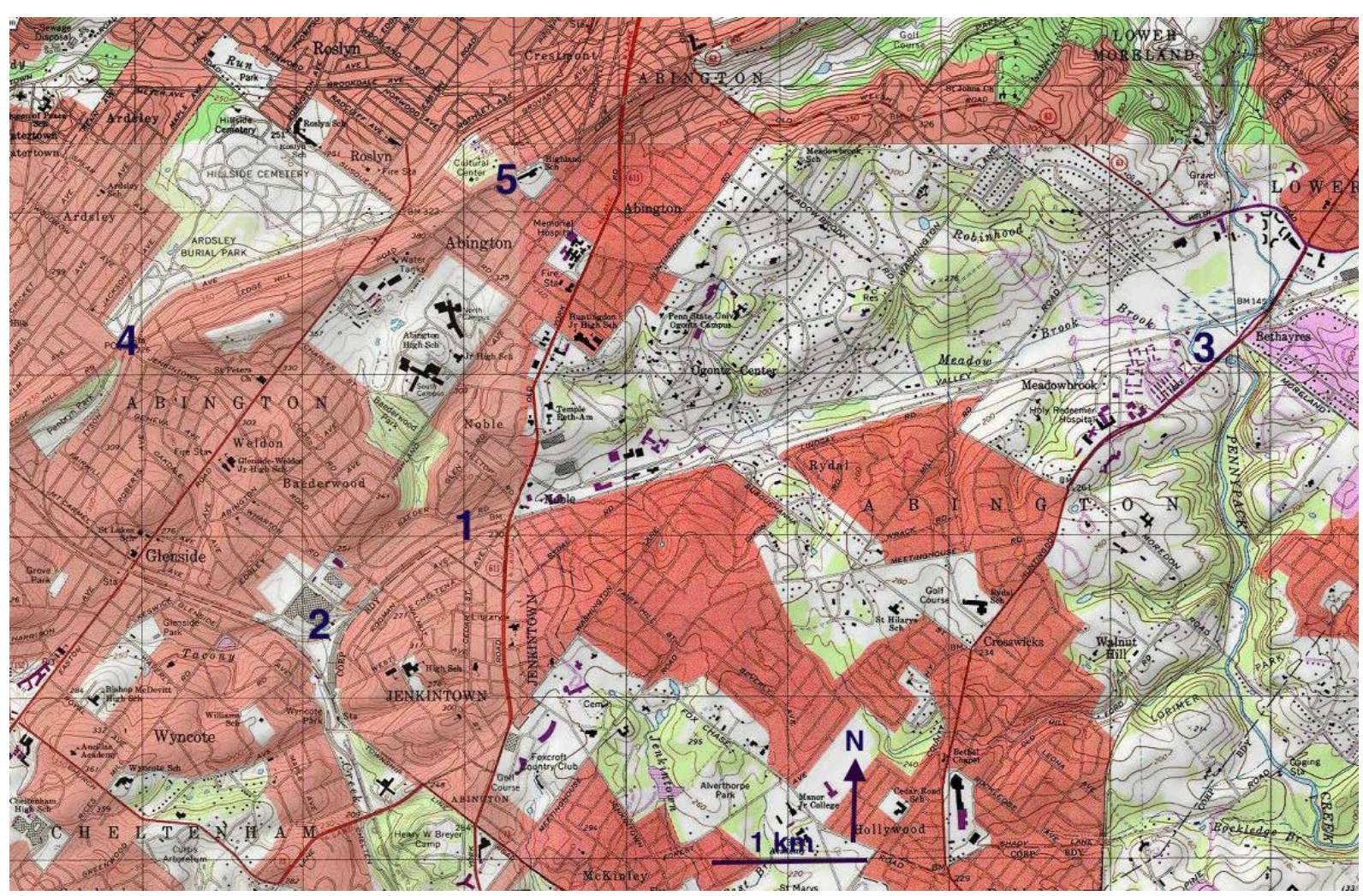

Figure 5. USGS 1:24,000 topographic maps (with 10-foot contour intervals in the west half and along the north edge and a 20-foot interval elsewhere) taken from Pennsylvania DCNR Interactive Map Resource website show the Jenkintown-Bethayres through valley and its drainage divide at (1), Tookany Creek at Jenkintown elbow of capture (2), Pennypack Creek (3), Weldon wind gap (4), and Highland wind gap (5)

The digital geologic map available at Pennsylvania DCNR Interactive Map Resources website shows the Jenkintown-Bethayres through valley to be located along the boundary between Precambrian felsic gneiss (north) and the Wissahickon Formation or schist of probable lower Paleozoic age (south). Near the Pennypack Creek valley a thin wedge of carbonate rock is located between the two metamorphic rock units. The contact is mapped as the Huntingdon Valley fault and small earthquakes in 1980 may have been associated with the fault (Bischke, 1980). Elevations to the north are generally more than 300 feet with still higher elevations found along the Edge Hill ridge. Elevations to the south are somewhat lower and only exceed 300 feet in the Jenkintown area. For its entire length the through valley floor is at least 100 feet lower than surrounding uplands on both sides and the valley provided a logical route for construction of the railroad line. The railroad was built in 1876 shortly before W.M. Davis left Pennsylvania to assume his Harvard position and he must have been aware of the railroad plans and construction.

The same low gradient west-southwest and west oriented channel that eroded the Laverock wind gap initiated the through valley erosion. At that time the channel floor elevation must have been at least as high as the Laverock wind gap floor elevation today or more than 120 feet higher the present day Tookany-Pennypack Creek divide (on the through valley floor). Tookany Creek valley headward erosion captured the west-southwest oriented flow when it also beheaded and reversed the channel further to east to create the east oriented Tookany Creek headwaters. Large volumes of west-southwest oriented water then flowed along the through valley alignment and significantly lowered the through valley floor. Southwest and then south oriented flow that had crossed the Edge Hill ridge at the Highland wind gap location entered the through valley along the present day Baederwood Creek alignment. Large volumes of water that were using the Seminary, Edge Hill, and Weldon, wind gaps from what was at that time the yet to be eroded Chester Valley crossed the Edge Hill ridge and joined the west-southwest oriented flow at the present day Tookany Creek elbow of capture. The combined flow at times must have been very large and it deepened and enlarged the Tookany Creek valley downstream from the Jenkintown rail junction elbow of capture.

Flow in the low gradient west-southwest oriented channel on the through valley alignment was next beheaded 
and reversed by headward erosion of the deeper south-oriented Pennypack Creek valley. A reversal of flow occurred when at least some water was still pouring across the Edge Hill ridge into the Tookany Creek drainage basin, especially at the Highland wind gap location (at that time Pennypack Creek valley headward erosion had not progressed far enough to behead the west or southwest oriented flow moving into the actively eroding Chester Valley) and for a time that remaining flow moved in a southwest and south direction along the present day Baederwood Creek alignment to enter the through valley where some water moved in an east direction to the new Pennypack Creek valley while the remaining water moved in a west direction to the Tookany Creek elbow of capture and then south in Tookany Creek. The east oriented flow eroded the present day east-northeast oriented Meadow Brook valley on the through valley floor. Headward erosion in the Chester Valley of west oriented Wissahickon tributary valleys and (to the east) of the Pennypack Creek valley beheaded all flow routes to the Tookany Creek drainage basin (the last being on the Baederwood Creek alignment) so as to create the through valley drainage divide.

\subsection{Cheltenham through Valley}

The Cheltenham through valley, unlike the Jenkintown-Bethayres through valley, is not easily seen on the ground or even on topographic maps, although railroad builders in 1906 used it when constructing a low-grade railroad line across the divide between Tookany and Pennypack Creeks. That rail line is seen in figure 6 (with a 20 -foot contour interval) and extends in a northeast direction from near the figure 6 southwest corner to near the figure northeast corner. Even a close look at the map may suggest evidence for the through valley's existence to be less than convincing. However, other types of evidence suggest southwest oriented water did flow across the Pennypack-Tookany Creek divide at this location.

The Cheltenham through valley links an elbow of capture where a southwest oriented Pennypack Creek segment turns to flow in an east-northeast direction with a Tookany (Tacony) Creek abrupt direction change where Tookany Creek turns from flowing in a southeast direction to flow in a southwest direction. Note how upstream from its southwest oriented segment Pennypack Creek flows in a southeast direction and how downstream from its east-northeast oriented segment Pennypack Creek flows in a south direction. Also note how a northeast oriented (or barbed) tributary joins Pennypack Creek at the point where it turns from flowing in a southwest direction to flow in an east-northeast direction and how the southwest oriented Pennypack Creek segment appears to line up with the southwest oriented Tookany (Tacony) Creek segment. This evidence suggests the southwest oriented Tookany (Tacony) and Pennypack Creek valley segments were eroded headward along the same southwest oriented flow channel.

The point where Pennypack Creek turns from flowing in a southwest direction to flow in an east-northeast direction and the barbed tributary provide evidence the Pennypack Creek valley eroded headward across a southwest oriented complex of diverging and converging flow channels. Headward erosion of the south oriented Pennypack Creek valley first beheaded and reversed flow on a west-southwest oriented channel that converged further downstream (on the beheaded channel) with a southwest oriented channel and the combined channel then continued along the present day southwest oriented Tookany (Tacony) Creek segment alignment. The barbed Pennypack Creek tributary is evidence of reversed flow on the beheaded southwest oriented flow channel. The reversed flow formed an east-northeast oriented channel that then captured flow in the converging southwest oriented flow channel, which beheaded flow moving across the present day drainage divide to the southwest-oriented Tookany (Tacony) Creek segment. 


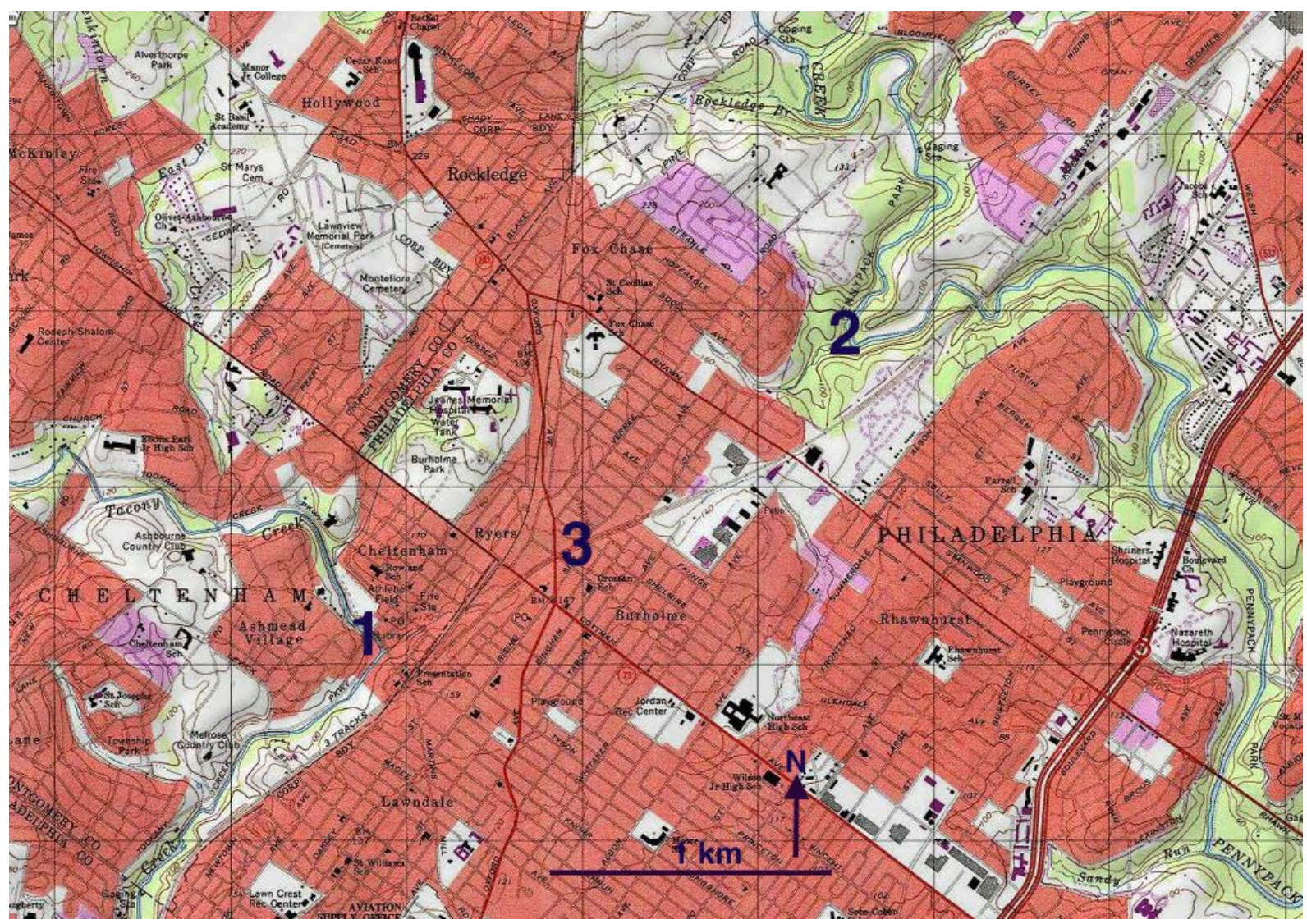

Figure 6. USGS 1:24,000 topographic map (with a 20-foot contour interval) taken from Pennsylvania DCNR Interactive Map Resources website showing the Tookany (Tacony) Creek abrupt direction change at Cheltenham (1), Pennypack Creek southwest-east-northeast direction change (2), and railroad in the shallow through valley crossing the Pennypack-Tookany Creek drainage divide (3)

\subsection{Barbed and other Tributaries to the Tookany Creek Valley Downstream from Jenkintown}

W.M. Davis probably was most familiar with the Tookany Creek valley downstream from Jenkintown (see figure 7) simply because it was closest to the Davis family home and would have been an attraction not only for recreation, but also for any young person developing an interest in the natural sciences. In addition young Davis probably had excellent access to much of the land in this area as his father, in addition to his coal company interests, also headed the Chelten Hills Land Association, which in 1854 purchased 1000 acres of farmland between the railroad and the Philadelphia city line, including lands adjoining the Tookany Creek valley (Rothschild, 1976, p. 68).

Between Jenkintown and the Philadelphia city line the Tookany Creek valley is eroded into the Wissahickon Formation schist with the deepest valley segment being between Jenkintown and Elkins Park. Today at several locations along that valley segment Tookany Creek flows over patches of exposed bedrock while bedrock outcrops can be seen along the creek banks and on valley walls and in the numerous railroad cuts. This valley segment in places has a V-shaped profile and depending on where and how measurements are made is from 100 to 200 feet deep. Tookany Creek down cutting is today proceeding extremely slowly as is retreat of the steep valley walls. Anyone making observations of present day erosion rates only in this Tookany Creek valley segment could reasonably conclude that similar conditions operating over extremely long periods of time developed the Tookany Creek valley as it exists today.

However, several features seen in figure 7 suggest the Tookany Creek valley had a very different history than the modern day erosion rates suggest. First is Mill Run, a northeast oriented Tookany Creek tributary originating south of the former Davis home and joining the southeast oriented Tookany Creek segment downstream from Elkins Park. Water in Mill Run makes a U-turn as it first flows in a northeast direction to join southeast oriented Tookany Creek, which then turns abruptly to flow in a southwest direction. The Mill Run evidence suggests 
headward erosion of a deep southeast oriented Tookany Creek valley segment beheaded and reversed a southwest oriented flow channel while the southwest oriented Tookany Creek valley segment suggests it had been eroded headward along a southwest oriented flow channel.

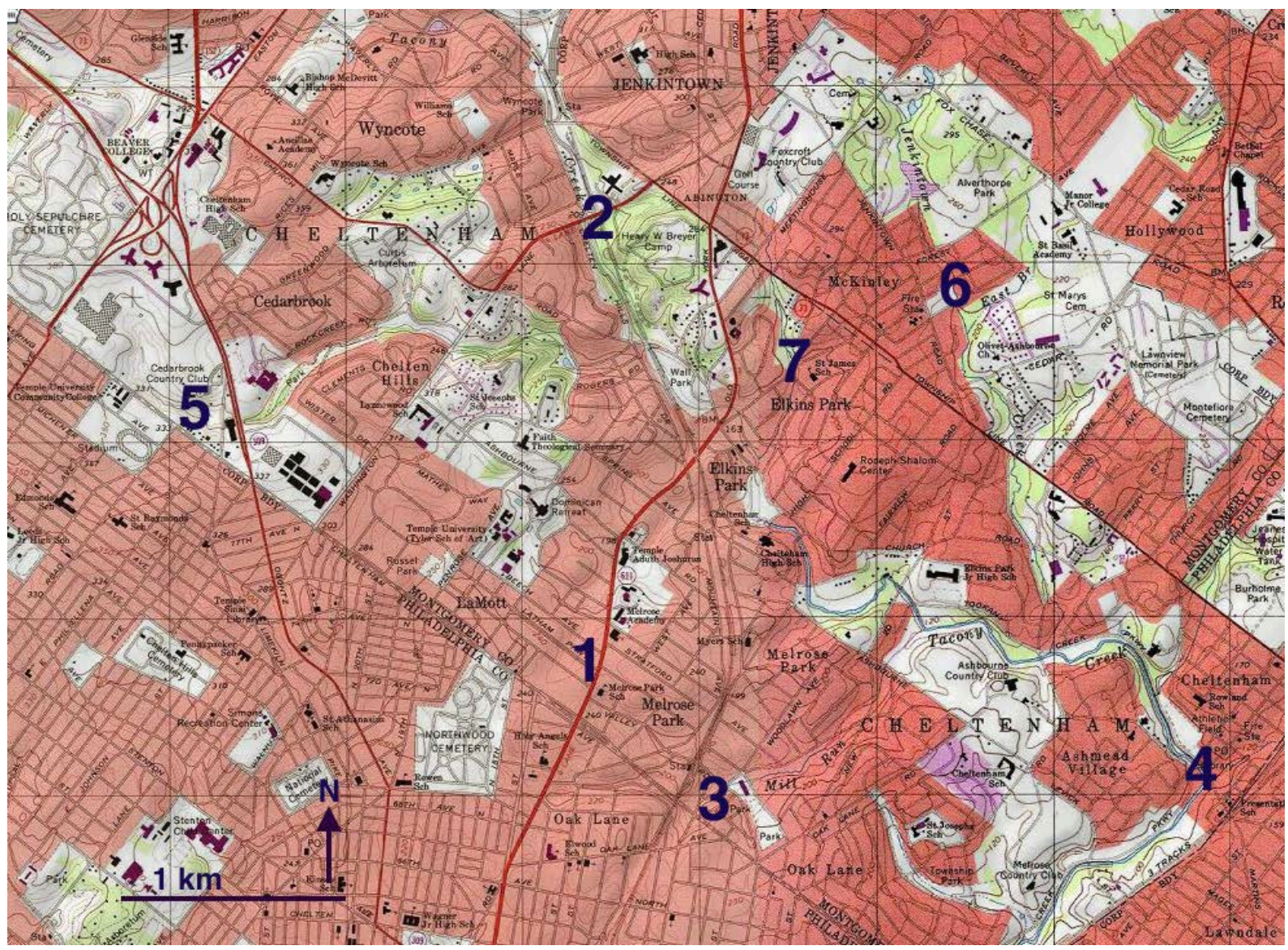

Figure 7. USGS 1:24,000 topographic map (with 10-foot contour interval in west and 20-foot contour interval in the east) taken from Pennsylvania DCNR Interactive Map Resources website showing Davis home location (1), Tookany (Tacony) Creek valley downstream from Jenkintown (2), Mill Run headwaters (3), Tookany (Tacony)

Creek Cheltenham direction change location (4), Cedar Brook headwaters (5), Jenkintown Creek (6), and an unnamed south oriented Tookany (Tacony) Creek tributary (7)

A close look at other Tookany Creek tributaries shows a deep northeast oriented valley extending through Wyncote and draining to Tookany Creek near the Jenkintown railroad station (the creek in that valley is shown in figure 1 but has since been incorporated into the Wyncote sewer system). This creek is another barbed tributary and provides further evidence the deep south oriented Tookany Creek valley eroded headward across southwest oriented flow. A tributary (Cedar Brook) originates at Cedarbrook Country Club and flows across lands the Chelten Hills Land Association once owned in a south and then northeast direction between Cedarbrook and Chelten Hills before continuing in an east direction to join Tookany Creek across from Wall Park. The east and northeast oriented Cedar Brook segments probably were formed when headward erosion of the deep south-oriented Tookany Creek valley beheaded and reversed west and southwest oriented flow channels and the south oriented headwaters valley was eroded by captured southwest oriented flow from what at that time was the yet to be beheaded and reversed southwest oriented channel that was later reversed to create the northeast oriented stream through Wyncote to the north.

East of the Tookany Creek valley short southwest oriented valleys suggest erosion by southwest oriented flow, but the two longest tributaries including Jenkintown Creek flow in south directions. The unnamed westernmost of these two south oriented tributaries turns in a southwest direction before joining Tookany Creek while Jenkintown Creek has southwest oriented headwaters and at least two southwest oriented tributaries. This 
evidence suggests the south oriented tributary valleys eroded headward across southwest oriented flow moving water into the newly eroded Tookany Creek valley with the unnamed south oriented tributary capturing the flow first and headward erosion of the south oriented Jenkintown Creek valley capturing the southwest oriented flow next. While not seen in figure 7, Pennypack Creek valley headward erosion east of figure 7 beheaded all southwest oriented flow to the Jenkintown Creek valley.

\section{Discussion}

The erosion history that emerges when wind gaps, through valleys, elbows of capture, and tributary and Tookany Creek valley orientations are explained is one of massive southwest oriented floods flowing across the entire region on what was probably a low gradient topographic surface equivalent in elevation to or higher than the highest ridges seen today. Floodwaters flowed in diverging and converging channels and were first captured by headward erosion of the deep south-oriented Wissahickon Creek valley. Headward erosion of the deep south-oriented Tookany Creek valley next captured the southwest oriented flow, but due to headward erosion of west oriented tributary valleys from the newly eroded Wissahickon Creek valley (in the Chester Valley area) was unable to erode headward across the Edge Hill quartzite ridge. Finally headward erosion of the deep south-oriented Pennypack Creek valley beheaded all southwest oriented flow routes moving to the Tookany Creek valley and also to the Chester Valley eastern end. This erosion history describes erosion events in a logical sequence and explains all observed landform features.

The origin of the massive southwest oriented floods described here cannot be determined from Tookany Creek or adjacent drainage basin landform evidence. All that can be conclusively determined is the floodwaters came from north and east of the region and were of great enough volume and duration to erode deep valleys into the preexisting topographic surface (and perhaps lowered that preexisting surface significantly). Melting of an Antarctic sized continental ice sheet, which may have contained 26,384,368 cubic kilometers of water according to a NASA distributed middle school exercise (Parkinson, 1999) could have produced floods capable of overwhelming all existing drainage systems and may have been responsible for the massive floods documented here. If so the floods crossed what are today south oriented Neshaminy Creek and Delaware River valleys located to the east and north of the Tookany Creek drainage basin. Evidence from other regions suggests the south oriented Delaware valley segment was eroded late in geologic time, perhaps between the Miocene and early Pleistocene (Braun, D. D., Pazzaglia, F. J., and Potter, N., 2003 p. 220). If so the previously established sequence of Wissahickon, Tookany, and Pennypack Creek valley headward erosion can be extended to include the Neshaminy Creek valley and the south and southeast oriented Delaware River valley segment (with headward erosion of the south oriented valleys beginning in the southwest and continuing to the northeast). This sequence may be evidence the south oriented valleys eroded headward from the head of the southwest oriented Delaware River valley segment (to which Tookany, Pennypack, and Neshaminy Creek now flow) as it eroded headward in a northeast direction along what was at that time a major southwest oriented flood flow channel.

The Tookany Creek drainage basin erosion history determined here is radically different from anything W. M. Davis ever described or that his erosion cycle or uniformitarianism paradigms even permit. Davis did not consider his geographical cycle or uniformitarianism ideas to be based on any specific geographic region (e.g. Davis, 1899), although in his mind he must have compared them many times with observations made while living in the Tookany Creek drainage basin. Davis did recognize his erosion cycle and uniformitarianism paradigms did not explain all landform evidence, but he knew of no satisfactory alternative paradigm that could. In his 1889(b) "Rivers and valleys of Pennsylvania" National Geographic Magazine paper, he stated, "If this theory of the history of our rivers is correct, it follows that any one river as it now exists is of so complicated an origin that its development cannot become a matter of general study and must unhappily remain only a subject for special investigation for some time to come” suggesting he knew his erosion cycle and uniformitarianism concepts could not explain much of the observed evidence.

The Tookany Creek drainage basin erosion history described here demonstrates that with a paradigm defined by headward erosion of deep valleys into a low gradient topographic surface over which immense floods moved water in shallower diverging and converging channel complexes it is possible to explain all observed wind gaps, through valleys, barbed tributaries, elbows of capture, and many valley segment orientations. The Davis uniformitarianism paradigm by not permitting catastrophic floods severely underestimated the amount of melt water released during continental ice sheet melting and unfortunately may be causing modern day geomorphologists to overlook wind gaps, through valleys, barbed tributaries, valley orientations, elbows of capture, and similar erosional landform features as important evidence that needs to be explained. Those erosional landform features exist and landform evolution studies of regions containing them must develop explanations that can explain all wind gap, through valley, barbed tributary, elbow of capture, and similar types 
of erosional landform evidence that may be present.

\section{References}

Baker, V. R (Ed.) (1981). Catastrophic flooding, the origin of the channeled scabland: Benchmark Papers in Geology (55), Dowden, Hutchinson \& Ross, 360p.

Bascom, F., Clark, W. B., Darton, N. H., Knapp, G. N., Kuemmel, H. B., Miller, B. L., \& Salisbury, R. D. (1909). Philadelphia folio: Norristown, Germantown, Chester, and Philadelphia, Pennsylvania-New Jersey-Delaware. Folios of the Geologic Atlas: 162.

Bischke, R, E. (1980). The Abington-Cheltenham, PA. Earthquake Sequence of March-May, 1980: Pennsylvania Geology, 11(5), 10-13.

Bishop, P. (2007). Long-term landscape evolution: linking tectonics and surface processes. Earth Surface Processes and Landforms, (32), 329-365. https://doi.org/10.1002/esp.1493

Braun, D. D., Pazzaglia, F. J., \& Potter, N. (2003), Margin of Laurentide Ice to the Atlantic Coastal Plain: Miocene-Pleistocene landscape evolution in the Central Appalachians (p. 220). In Easterbrook, D. (Ed.), Quaternary Geology of the United States: INQUA 2003 Field Guide Volume: Desert Research Institute, Reno, NV.

Bretz, J. H. (1923). The Channeled Scabland of the Columbia Plateau. Journal of Geology, (31), 617-649. https://doi.org/10.1086/623053

Camburn, R. S. (1977). The Story of Greater Glenside including the towns of Ardsley, Edge Hill, North Hills, and Weldon: revised edition (p.120), Glenside Free Library, Glenside, PA.

Chorley, R. J., Beckinsale, R. P., \& Dunn, A. J. (1973). The History of the Study of Landforms or the Development of Geomorphology: Volume 2: The life and work of William Morris Davis. Routledge, New York. 874p.

Clausen, E. (2015). Exploring the Geography of William Morris Davis' Pennsylvania roots. Pennsylvania Geographer, 53(1), 44-65.

Davis, W. M. (1889a). A river pirate. Science 13, pp. 108-9

Davis, W. M. (1889b). The rivers and valleys of Pennsylvania. National Geographic Magazine (1), pp. 183-253.

Davis, W. M. (1895). Bearing of physiography on uniformitarianism. Bulletin Geological Society of America, (7), 8-11.

Davis, W. M. (1899). The Geographical Cycle: Geographical Journal, 14, (pp. 481-504). Reprinted in: Davis, W. M., 1909, Geographical Essays: Ginn and Company, New York, pp. 249-278

Hack, J. T. (1957). Studies of longitudinal stream profiles in Virginia and Maryland. United States Geological Survey Professional Paper 294-B, 45-97.

Horton, R. E. (1945). Erosional development of streams and their drainage basins: hydrophysical approach to quantitative morphology. Bulletin of the Geological Society of America, (56), 275-370. https://doi.org/10.1130/0016-7606(1945)56[275:EDOSAT]2.0.CO;2

Orme, A. R. (2007) The rise and fall of the Davisian cycle of erosion: prelude, fugue, coda, and sequel: Physical Geography, (28), 474-506. https://doi.org/10.2747/0272-3646.28.6.474

Parkinson, C. L. (1999) Ice Sheets and sea level rise: from The PUMAS Collection. Retrieved 10/20/2016 from http://pumas.jpl.nasa.gov/examples/index.php

Pennsylvania Department of Conservation and Natural Resources (2016). DCNR Interactive Map Resources, Retrieved 10/20/2016 from http://www.dcnr.state.pa.us/learn/interactivemapresources/index.htm

Potter, N. (1999). Part V: Physiography: In C. H. Schultz (Ed), The Geology of Pennsylvania (pp. 342-344), Pennsylvania Geological Survey and Pittsburgh Geological Society, Harrisburg and Pittsburgh, PA.

Rothschild, E. W. (1976). A History of Cheltenham Township: Montgomery County, PA. Cheltenham Township Historical Commission, Cheltenham Township, PA. 81p.

Strahler, A. N. (1952). Dynamic basis of geomorphology. Geological Society of America Bulletin, (63), 923-938. https://doi.org/10.1130/0016-7606(1952)63[923:DBOG]2.0.CO;2

United States Geological Survey Historical Map Collection (1896). Germantown, PA 1:62,500 scale topographic map. Retrieved 10/20/2016 from http://ngmdb.usgs.gov/maps/TopoView/viewer/\# 
United States Geological Survey Historical Map Collection (1997). Frankford, PA 1:24,00 scale topographic map. Retrieved 10/24/2016 from http://ngmdb.usgs.gov/maps/TopoView/viewer/\#

United States Geological Survey Historical Map Collection (1997). Germantown, PA 1:24,000 scale topographic map. Retrieved 10/20/2016 from http://ngmdb.usgs.gov/maps/TopoView/viewer/\#

United States Geological Survey Historical Map Collection (1999). Ambler, PA 1:24,00 scale topographic map. Retrieved 10/20/2016 from http://ngmdb.usgs.gov/maps/TopoView/viewer/\#

United States Geological Survey Historical Map Collection (1999). Hatboro, PA 1:24,00 scale topographic map. Retrieved 10/20/2016 from http://ngmdb.usgs.gov/maps/TopoView/viewer/\#

\section{Copyrights}

Copyright for this article is retained by the author(s), with first publication rights granted to the journal.

This is an open-access article distributed under the terms and conditions of the Creative Commons Attribution license (http://creativecommons.org/licenses/by/4.0/). 